\title{
PENDIDIKAN POLITIK KEBANGSAAN BERBASIS PESANTREN
}

\author{
Romy Hermawan ${ }^{1}$, Rispa Ngindana ${ }^{2}$ \\ 1 Universitas Brawijaya \\ email: romy@ub.ac.id \\ 2Universitas Brawijaya \\ korespondensi email: rispangindana@ub.ac.id
}

\begin{abstract}
Islamic boarding school as a social institution that experiences dialectics both inside and outside the boarding school which is a projection of the boarding school community itself. The role of Islamic boarding schools which initially focused on character and religious education, now forces them to make changes internally such as the education system, social construction and public and religious education providers including political education. The purpose of this activity is to increase awareness of the importance of political education for students, increase understanding of political education in contrast to politics for students and increase understanding of the importance of political education as an effort to educate students as NKRI people who embrace the Pancasila Democracy. This community service method uses a social approach by analyzing the situation of khalayk or certain organizations, namely santri. The results of this activity show the understanding of the students of Miftahul Ulum Islamic Boarding School, Mentaraman Village, Donomulyo District initially argued that political behavior is bad behavior, but after it was conveyed that so far in daily life political behavior has been unconsciously realized. With this activity in the form of national political education it is hoped that it can increase students 'knowledge about national politics, in addition it is expected to further increase students' awareness that politics is not negative behavior.
\end{abstract}

Keywords: politic education; service quality; public health.

\begin{abstract}
ABSTRAK
Pondok pesantren sebagai salah satu institusi sosial yang mengalami dialektika baik di dalam maupun di luar lingkungan pondok pesantren yang merupakan proyeksi dari masyarakat pesantren itu sendiri. Peran pondok pesantren yang awalnya berfokus pada pendidikan karakter dan agama, kini memaksa mereka melakukan perubahan di internalnya seperti sistem pendidikan, konstruksi sosial dan penyelenggara pendidikan agama dan umum termasuk pendidikan politik. Tujuan kegiatan ini adalah untuk meningkatkan kesadaran terhadap pentingnya pendidikan politik bagi santri, meningkatkan pemahaman pendidikan politik berbeda dengan berpolitik bagi santri dan meningkatkan pemahaman pentingnya pendidikan politik sebagai upaya mencerdaskan santri sebagai masyarakat NKRI yang menganut Demokrasi Pancasila. Metode pengabdian masyarakat ini menggunakan pendekatan sosial dengan melakukan analisis situasi terhadap khalayak atau organisasi tertentu yaitu santri di pondok pesantren. Hasil kegiatan ini menunjukkan pemahaman para santri Pondok Pesantren Miftahul Ulum, Desa Mentaraman, Kecamatan Donomulyo awalnya berpendapat bahwa perilaku politik adalah perilaku yang tidak baik, namun
\end{abstract}


setelah disampaikan bahwa selama ini dalam kehidupan sehari-hari sudah melakukan perilaku politik secara tidak disadari. Dengan adanya kegiatan ini yang berupa pendidikan politik kebangsaan diharapkan dapat meningkatkan pengetahuan santri tentang politik kebangsaan, selain itu diharapkan semakin meningkatkan kesadaran santri bahwa berpolitik itu bukan perilaku negatif.

Kata Kunci: pendidikan politik; kualitas pelayanan; kesehatan masyarakat.

\section{PENDAHULUAN}

Berdirinya pondok pesantren di Indonesia berakar dari tradisi Islam yang merupakan model pendidikan dari pondok pesantren Indonesia. Pondok pesantren di Indonesia memiliki istilah yang beraneka ragam (Syafe'i, 2017). Di Jawa khususnya Sunda dan Madura disebut pesantren atau pondok pesantren, di Aceh disebut dayah atau rangkang, di Sumatera Barat (Minangkabau) disebut surau. Keberadaan pondok pesantren tidak hanya untuk memenuhi kebutuhan pendalaman dan penyiaran agama Islam tetapi juga untuk sarana mendidik masyarakat Indonesia (Furqan, 2019).

Pondok pesantren sebagai salah satu institusi sosial yang mengalami dialektika baik internal maupun eksternal. Dialektika ini merupakan gambaran dari masyarakat pondok pesantren itu sendiri (Rusydiyah, 2017). Pondok pesantren pada awalnya ditempatkan sebagai sub-culture, agent of development, dan pendidikan keagamaan. Sebagai agent of development, pondok pesantren dari dulu lebih dekat dengan masyarakan pinggiran dan pedesaan sehingga pondok pesantren lebih luwes dalam mengedukasi masyarakat. Pendidikan keagamaan di Indonesia merupakan salah satu jenis pendidikan yang ada dalam sistem pendidikan nasional Indonesia sebagaimana diatur dalam Undang-Undang Nomor 20 Tahun 2003 tentang Sistem Pendidikan Nasional (Nugroho, 2016).

Menurut Maesaroh \& Achdiani (2018) Pemerintah dan masyarakat memiliki peran dalam bidang pendidikan, sosial, budaya dan ekonomi. Peranperan itulah akhirnya memaksa pesantren melakukan perubahan internal, diantaranya:

1. Sistem pendidikan pondok pesantren menyelenggarakan sistem pendidikan formal, nonformal dan pendidikan agama. Hal ini untuk membentuk santri-santri yang memiliki kapabilitas sesuai dengan bidangnya.

2. Konstruksi sosial pondok pesantren adalah sebagai institusi penyeimbang akal dan hati.

3. Pesantren sebagai penyelenggara pendidikan agama, sekaligus sebagai penyelenggara pendidikan umum lainnya.

Menurut Thahir (2014) fungsi pesantren adalah sebagai berikut (a) Sebagai institusi pendidikan, dalam hal ini pesantren berfungsi dalam proses pemberdayaan bangsa secara integral dan secara khusus bertanggungjawab atas keberlangsungan pengajaran agama Islam sehingga dapat menghasilkan manusia yang beriman memiliki kualitas moral dan intelektual; (b) Sebagai institusi sosial. Pondok pesantren mengakomodir semua santri yang berasal 
dari berbagai jenis golongan masyarakat dan permasalahan hidupnya; (c) Sebagai lembaga penyiaran agama. Hal ini diilhami dari fungsi masjid yang ada di pondok pesantren. Pesantren yang beroperasi juga berfungsi sebagai masjid umum, yaitu sebagai tempat studi agama dan ibadah umum. Masjid pondok pesantren sering digunakan untuk melakukan diskusi keagamaan dan seterusnya oleh masyarakat umum. Pada kasus ini, masyarakat sebagai pengikut untuk mendapatkan agama ilmu dan dalam setiap kegiatan yang diselenggarakan oleh masjid pondok pesantren.

Metode pendidikan pesantren lebih pada penanaman ilmu bukan pengembangan ilmu, karena ilmu agama itu adalah given. Hal ini terlihat pada metode pendidikan pesantren yang cenderung menggunakan metode hafalan (Afif, 2019). Pendidikan politik memiliki makna yang berbeda dengan pendidikan dan politik jika didefinisikan secara terpisah. Untuk memahami arti pendidikan politik kita harus memahami definisi, tujuan dan fungsi pendidikan politik. Terdapat perdebatan yang hingga saat ini belum terselesaikan terkait dengan penerapan pendidikan politik dalam masyarakat. Perdebatan ini muncul karena adanya perbedaan definisi pendidikan politik oleh elit penguasa dengan masyarakat biasa. Sehingga sering ditemukan pendidikan politik ini hanya akan bermakna positif bagi penguasa dan sebaliknya bagi masyarakat biasa (Wahyuningroem, 2011).

Beberapa permasalahan yang dapat diidentifikasikan dari hasil analisis situasi tersebut di atas adalah:

1. Kesadaran terhadap pentingnya pendidikan politik bagi santri.

2. Pemahaman pendidikan politik berbeda dengan berpolitik bagi santri.

3. Pemahaman pentingnya pendidikan politik sebagai upaya mencerdaskan santri sebagai masyarakat NKRI yang menganut Demokrasi Pancasila.

Tujuan kerja secara spesifik ini disusun untuk mendapatkan kondisi baru yang dihasilkan melalui kegiatan pengabdian kepada masyarakat. Adapun tujuan pengabdian kepada masyarakat ini adalah untuk meningkatkan kesadaran terhadap pentingnya pendidikan politik bagi santri dan meningkatkan pemahaman pendidikan politik berbeda dengan berpolitik bagi santri. Serta pemahaman pentingnya pendidikan politik sebagai upaya mencerdaskan santri sebagai masyarakat NKRI yang menganut Demokrasi Pancasila.

Peran pondok pesantren dalam politik dapat dilihat dari hasil pengkajian Ernas \& Siregar (2010) tentang dampak keterlibatan pesantren dalam politik dapat dikaji melalui 3 (tiga) pendekatan toritis yaitu teori hubungan agama dan negara, teori ekonomi politik, dan teori hegemoni politik. Berdasarkan pendekatan teori negara dan agama, posisi pesantren dalam negara memiliki akses yang sangat terbuka untuk berpartisipasi aktif dalam kegiatan bernegara termasuk kegiatan berpolitik. Berdasarkan pendekatan teori ekonomi politik, menunjukkan bahwa interaksi politik selalu bermotif ekonomi sehingga memunculkan konsep high cost politics, hal ini dapat terlihat dari adanya transaksi uang dengan suara dapat dilakukan dengan 
berbagai cara baik langsung maupun tidak. Transasksi langsung mengandung pengertian transaksi yang dilakukan kelompok kepentingan langsung, yakni memberikan uang dengan janji suara yang akan disalurkan melalui pesantren. Sedangkan transaksi tidak langsung dapat berupa benda atau apa saja yang dapat dipertukarkan dengan kepentingan kiai maupun "pembangunan" pesantren. Berdasarkan teori hegemoni ini lebih menekankan peran pesantren sebagai objek politik (Hamid, 2010).

Secara etimologi, pendidikan politik dalam bahasa Inggris sering disebut sebagai political socialization. Makna pendidikan politik dan sosialisasi politik ini hampir sama, namun sosialisasi politik dapat ditafsirkan sebagai pendidikan politik dalam arti luas. Pendidikan politik dalam arti luas yang dimaksud adalah suatu usaha yang dilakukan secara sadar untuk mengubah ketidaktahuan masyarakat akan suatu sistem politik sehingga masyarakat dapat mengetahui, memahami dan meresapi nilai-nilai ideal dari sebuah sistem politik yang sedang disusun (JIS et al., 2016).

Pendidikan politik adalah proses pembebasan perilaku psikologis dan mental warga negara dengan menyadarkan dan mengkonkretkan mereka agar memiliki kesadaran yang meningkat yang memungkinkan mereka untuk berpartisipasi secara penuh, aktif, dan produktif dalam proses perkembangan komunitas mereka. Pendidikan politik melakukan fungsi menimbulkan kesadaran politik dalam suatu masyarakat melalui persiapan orang-orang untuk dunia sosial-politik di mana mereka hidup sehingga mereka akan menjadi berguna bagi diri mereka sendiri dan berkontribusi secara berarti kepada pertumbuhan dan perkembangan masyarakat mereka (Oladejo \& Oni, 2017). Definisi yang lebih singkat yakni pendidikan politik sebagai upaya menanamkan pengetahuan, sikap dan keterampilan yang akan memungkinkan mereka (warga negara) untuk berpartisipasi dalam proses politik (Borge, 2016). Pendidikan politik memiliki dimensi sebagai berikut: (1) Kemanusiaan; (2) Tidak ada kepentingan pribadi; (3) Kepemimpinan pragmatis; (4) Kepemimpinan yang transformatif; (5) Moralitas dan etika; (6) Proses politik (Thebe, 2017). Jadi dalam pendidikan politik ini pemahaman dan pengetahuan yang disampaikan itu tentang kemanusiaan, kepentingan umum, kepemimpinan pragmatis, kepemimpinan transformatif, etika dan moral, serta proses politik.

Dari segi kepemimpinan dan pelayan publik, para pemimpin menggunakan kekuatan sebagai cara untuk mencapai tujuan kelompok dan kekuasaan sebagai sarana untuk memfasilitasi pencapaian mereka. Ini berarti bahwa kepemimpinan membutuhkan tujuan yang selaras sedangkan kekuatan politik tidak membutuhkan tujuan yang selaras, melainkan membutuhkan ketergantungan. Kepemimpinan membutuhkan kesesuaian antara tujuan para pemimpin dan tujuan kelompok sedang dipimpin. Kepemimpinan berkonsentrasi pada pengambilan keputusan dan bagaimana seharusnya berbagi dengan mereka yang dipimpin, sementara kekuatan politik berkonsentrasi pada taktik untuk mendapatkan kepatuhan dan instruksi. 
Kekuatan politik digunakan untuk mengendalikan individu dan / atau kelompok lain. Terlepas dari kebutuhan akan profesionalisme, perilaku yang baik, anti korupsi dan good governance, tetap menjadi masalah pelik dan tidak dapat dibiarkan tanpa kritik. Penempatan jabatan politis cenderung menghasilkan para pemimpin politik dan pejabat publik yang relatif tidak berpengalaman dan tidak paham akan politik itu sendiri. Penempatan kader telah menciptakan struktur kepemimpinan partai dan telah memberikan dominasi yang sangat besar kepada para pemimpin politik, menghasilkan situasi-situasi di mana para pemimpin seperti itu tidak mau atau tidak mampu meminta pertanggungjawaban para pejabat publik (Olum, 2014). Para pemimpin politik yang tidak berpengetahuan politik dan tidak berpengalaman mengakibatkan runtuhnya pemberian layanan, krisis ekonomi dan penderitaan manusia karena lingkungan yang menuntut banyak segi dan multidimensi dengan karakteristik unik dan perspektif beragam yang memerlukan pendekatan dan strategi yang berbeda. Karakteristik unik ini tidak terbatas pada faktor sosialekonomi, perbedaan politik, kepekaan terhadap budaya, masalah gender, agama. Fenomena-fenomena ini menuntut kota untuk menggunakan kapasitas administratif dan keuangan mereka untuk mencapai tingkat kinerja setinggi mungkin (Thebe, 2017).

Pendidikan politik di pondok pesantren selama ini sudah dilaksanakan dengan tidak sengaja, karena tidak menggunakan metode dan kurikulum tertentu. Berbagai aktifitas yang mengarah pada aktifitas penddiikan politik atau dlaam hal ini yang tidak sengaja mendidik santri tentang berpolitik adalah aktifitas seperti diskusi yang memberikan kebebasan paras antri untuk menyampaikan pendapatnya di majelis, menghargai dan menghormati perbedaan pandangan orang lain, menghargai dan menghormati budaya para santri, pembelajaran tentang moral dan etika dalm hubungan antar manusia dan toleransi. Menurut Mukodi (2016) dalam temuan disertasinya di Pondok Tremas ada lima aktifitas di pondok pesantren yang mengkondisikan para santri memahami nilai-nilai politik, yakni: 1) forum diskusi (musyawarah) kitab; 2) kajian al-Fiqh 'alāal Madhāhib al-Arba'ah; 3) forum khițābiyah; 4) praktik budaya demokrasi; 5) kajian bath al-masāil.

Regulasi pertama tentang pendidikan politik di Indonesia diatur dalam Instruksi Presiden (Inpres) Nomor 12 Tahun 1982 tentang Pendidikan Politik Generasi Muda. Tahun 2008 dikeluarkannya Undang-Undanga Nomor 2 Tahun 2010 tentang Partai Politik. Kemudian disusul dengan dikeluarkannya Peraturan Menteri Dalam Negeri Nomor 36 Tahun 2010 tentang Pedoman Fasilitasi Penyelenggraan Pendidikan Politik. Menurut peraturan menteri ini, pendidikan politik didefinisikan sebagai proses pembelajaran dan pemahaman tentang hak, kewajiban, dan tanggung jawab setiap warga negara dalam kehidupan berbangsa dan bernegara.

Pendidikan politik sering dianggap sebagai bagian dari sosialisasi politik melalui pendekatan pendidikan dan ilmu politik. Pendidikan politik merupakan elemen penting dalam mengembangkan dan memperkuat 
masyarakat demokratis, selain itu, pendidikan politik juga sebagai alat partai politik memberikan pemahaman kepada masyarakat akan maksud dan tujuan keberadaannya. Dari sudut pandang ilmu pendidikan atau bidang pendidikan, pendidikan politik diberikan untuk menamkan nilai yang sesuai bagi warga negara. Sedangkan dari sisi ilmu politik, pendidikan politik merujuk pada kegiatan pemerintah yang bertujuan memobilisasi tugas pembangunan bangsa dan inklusi publik termasuk kegiatan partai politik. Pendidikan politik berfokus pada belajar bagaimana sistem demokrasi dalam kinerja pemerintah, bertujuan untuk mengajar bagaimana kelompok kepentingan mengejar tujuan mereka, dan menganalisa proses kekuasaan politik, ekonomi dan lembaga institusi lain (Triono, 2017).

Berbeda dengan pendidikan politik, "pendidikan kewarganegaraan" mencakup konsep yang lebih luas dalam membangun masyarakat yang demokratis. Ini termasuk peran dan tanggung jawab yang relevan dari warga, pemerintah, politik dan kepentingan khusus, media massa, dan sektor bisnis dan nirlaba, dan pentingnya pemilu periodik dan kompetitif (Sunarso, 2006). Ada tiga komponen inti pendidikan kewarganegaraan yang menekankan kesadaran warga dan partisipasi warga negara kewarganegaraan, pengetahuan, disposisi sipil atau nilai, dan keterampilan sipil. Semua elemen ini membantu orang memperoleh pengetahuan dan keterampilan yang diperlukan untuk menjadi warga yang terinformasi dan kompeten.Tidak seperti pendidikan pemilih dan pendidikan pemilu, pendidikan kewarganegaraan tidak harus dilakukan oleh otoritas pemilu (Kalidjernih \& Winarno, 2019).

Ada berbagai pendapat mengenai tujuan pendidikan politik. Bagi sebagian orang, pendidikan politik adalah persiapan ketika seseorang akan memiliki kesempatan untuk berpikir tentang masalah politik, membentuk keputusan pribadi mereka, dan untuk mewujudkan keinginan mereka. Bagi sebagian orang, pendidikan politik adalah sebuah proses menyerahkan kesempatan kepada siswa yang sudah cukup umur untuk belajar tentang politik kelompok dan perkumpulan mereka serta keterlibatan mereka dalam kelompok-kelompok sosial di masyarakat. Pada akhirnya, tujuan dari pendidikan politik adalah terbentuknya sosok individu yang dibutuhkan oleh sistem politik dalam suatu masyarakat.

Dalam kaitannya dalam membentuk masyarakat yang demokratis, pendidikan politik merupakan alat yang sesuai untuk membuka wawasan dan memperdalam kesadaran, partisipasi dan keterlibatan individu dalam mewujudkan demokratisasi. Apa sebenarnya demokratisasi ini? Secara umum, kita memahami demokratisasi sebagai suatu proses mendekati demokrasi. Demokrasi di Indonesia adalah demokrasi yang mengutamakan musyawarah atau perundingan, bukan intimidasi-intimidasi pihak-pihak yang berkuasa. Demokrasi yang diharapkan adalah demokrasi yang penuh dengan ketenangan tanpa rasa kekhawatiran akan untung dan rugi. Konsep demokratisasi memiliki tujuan untuk membentuk pemilihan yang bebas dan adil selain itu demokratisasi dianggap sebagai proses dimana kebebasan sipil 
dan hak-hak politik yang diperlukan untuk mencapai tujuan ini direalisasikan dan dipertahankan.

Demokrasi adalah konsep politik yang menjadi pilihan sistem politik di berbagai negara dunia ketiga pada dua dasawarsa terakhir (Heru Nugroho, 2012). Nadir \& Wardani (2018) menjelaskan bahwa dalam demokrasi Pancasila, pendidikan politik harus berintikan: (1) Nilai Ketuhanan Yang Maha Esa, tidak boleh ajaran-ajaran lain masuk dan disebarkan melalui sarana pendidikan politik; (2) Penghormatan, pengakuan dan pemartabatan hak asasi manusiaselaku pemilih dalam pemilihan Presiden dan wakil Presiden; (3) Persamaan dan kelayakan bagi setiap pemilih baik dari golongan partai pengusung Presiden maupun bukan; (4) Mencirikan semangat keadilan sosial bagi seluruh rakyat Indonesia sebagai nilai hakiki; (5) Mengagungkan moral dan budi pekerti yang luhur dalam kehidupan berbangsa serta bernegara; (6) Menegakkan partsipasi serta transparansi pada setiap proses pengambilan kebijakan bagi pemerintah sebagai ciri khas negara hukum Pancasila (asas musyawarah-mufakat).

Dengan mengilhami inti demokrasi Pancasila, pendidikan politik ini selain meningkatkan pemahaman tentang kemanusiaan, kepentingan umum, kepemimpinan pragmatis, kepemimpinan transformatif, etika dan moral, serta proses politik sehingga dapat mengetahui posisinya dalam proses politik, selain itu juga pendidikan politik ini diharapkan mampu untuk menegakan Pancasila dan UUD 1945 terhadap tantangan internal maupun eksternal. Saat ini tantangan internal yang dihadapi antara lain hukum masyarakat, etika politik masyarakat, melemahnya persatuan dan kesatuan, melemahnya gotong royong dan kerukunan, dan potensi-potensi egosentrismen lokal yang bertentangan dnegan Pancasila. Selain itu masuknya paham radikalisme dan fundamentalisme yang menggunakan latar belakang agama, dimana paham tersebut mengembangkan doktrin atau ajaran kepada penganutnya atau anggotanya untuk membentuk suatu negara baru. Paham-paham semacam ini tidak hanya pengganggu keutuhan bangsa Indonesia tetapi juga mengancam Dasar Negara sekaligus Ideoloigi bangsa yakni Pancasila.

\section{METODE PELAKSANAAN}

Metode yang dilaksanakan menggunakan sistem tindakan yang akan dilakukan dengan tahapan sebagaimana berikut:

\section{Analisis situasi masyarakat}

Tahapan ini terdiri dari penentuan sasaran pengabdian diantaranya (a) Khalayak umum; (b) Organisasi masyarakat tertentu; (c) Perkumpulan tertentu dan (d) Populasi masyarakat dalam kriteria tertentu. Penetuan permasalahan atau isu permasalahan yang akan dianalisis yaitu secara umum melibatkan multi disiplin ilmu serta secara khusus pada satu atau dua bidang isu permasalahan tertentu.

Dalam pengabdian kepada masyarakat ini, pengabdi melakukan analisis situasi terhadap khalayak atau organisasi tertentu yaitu santri pada 
pondok pesantren. Adapun bidang permasalahan yang dianalisis adalah permasalahan secara terbatas tentang pemahaman politik pada masyarakat pondok pesantren dalam sistem demokrasi Pancasila.

\section{Pendekatan sosial}

Pendekatan sosial merupakan pendekatan yang menjadikan masyarakat sasaran sebagai subjek bukan objek dari kegiatan pengabdian masyarakat. Masyarakat sasaran dalam hal ini adalah santri pada pondok pesantren.

Adapun Pelaksanaan kegiatan dilaksanakan di Pondok Pesantren Miftahul Ulum Desa Mentaraman Kecamatan Donomulyo Kabupaten Malang pada bulan Januari sampai dengan Maret tahun 2019 dengan memberikan kegiatan sosialisasi dan pemberian modul pendidikan politik kebangsaan kepada para santri. Kegiatan ini melibatkan tim pengabdi, para pengasuh dan para santri.

Setelah kegiatan dilaksanakan tim pengabdi melakukan evaluasi hasil kegiatan untuk mengetahui hasil perubahan tingkat pemahaman dari sebelum dan setelah diterapkannya pendidikan politik pada santri di lingkungan pondok pesantren.

\section{HASIL DAN PEMBAHASAN}

Universitas Brawijaya Malang, khususnya Fakultas IImu Administrasi di masyarakat dikenal sebagai lembaga pendidikan yang memiliki kepedulian terhadap permasalahan yang berkembang di masyarakat. Kegiatan pendidikan politik kebangsaan berbasis pesantren di Pondok Pesantren Miftahul Ulum, Desa Mentaraman, Kec. Donomulyo, Kabupaten Malang berjalan sesuai dengan tujuan kegiatan. Pengelola pondok pesantren membantu persiapan acara dan mengkoordinir peserta kegiatan. Peserta yang dimaksud disini adalah santri di Pondok Pesantren Miftahul Ulum, Desa Mentaraman, Kec. Donomulyo, Kabupaten Malang. Lokasi kegiatan penyuluhan adalah di salah satu aula Pondok Pesantren Miftahul Ulum, Desa Mentaraman, Kec. Donomulyo, Kabupaten Malang. Kegiatan dimulai dengan perkenalan masing-masing narasumber/pemateri baik dari Fakultas IImu Administrasi Unversitas Brawijaya maupun dari pengurus pondok pesantren, kemudian kegiatan selanjutnya narasumber/pemateri melakukan "warming up" untuk mengukur pengetahuan peserta tentang politik, bela negara dan demokrasi.

Hasil yang didapatkan (Output) dari kegiatan pengabdian kepada masyarakat yaitu para santri diberi pengetahuan tentang definisi politik, fungsi politik, tujuan pendidikan politik, partisipasi, bentuk-bentuk partisipasi politik, demokrasi politik, 11 pilar sistem demokrasi politik, warga negara, bangsa, demokrasi, dan menjadi warga negara aktif. Selain itu, hasil evaluasi terhadap tingkat pemahaman para santri terkait dengan pendidikan politik kebangsaan menunjukan bahwa pada awalnya mereka berpendapat bahwa perilaku politik adalah perilaku yang tidak baik, namun setelah disampaikan bahwa selama ini 
dalam kehidupan kita sehari-hari sudah melakukan perilaku politik secara tidak disadari. Perilaku politik tidak hanya saat pemilihan umum namun dalam kehidupan sehari-hari tidak terlepas dari perilaku ini.

Sedangkan outcome kegiatan ini adalah program pengabdian masyarakat yang berupa pendidikan politik kebangsaan ini diharapkan dapat meningkatkan pengetahuan santri tentang politik kebangsaan, selain itu mampu meningkatkan pengetahuan santri bahwa berpolitik itu bukan perilaku negative. Selain itu, pendidikan politik melalui penyuluhan mampu meningkatkan kesadaran para santri untuk berpartisipasi dalam pesta demokrasi dan aktifitas politik baik.

Materi yang disosialisasikan terkait dengan definisi politik, fungsi politik, tujuan pendidikan politik, partisipasi, bentuk-bentuk partisipasi politik, demokrasi politik, 11 pilar sistem demokrasi politik, warga negara, bangsa, demokrasi, dan menjadi warga negara aktif. Selain kegiatan sosilisasi, dilakukan juga pengukuran feedback kepemahaman peserta terhadap meteri yang disajikan. Berikut adalah grafik rata-rata tingkat kepemahaman peserta terhadap materi ini sebagaimana pada gambar 1 .

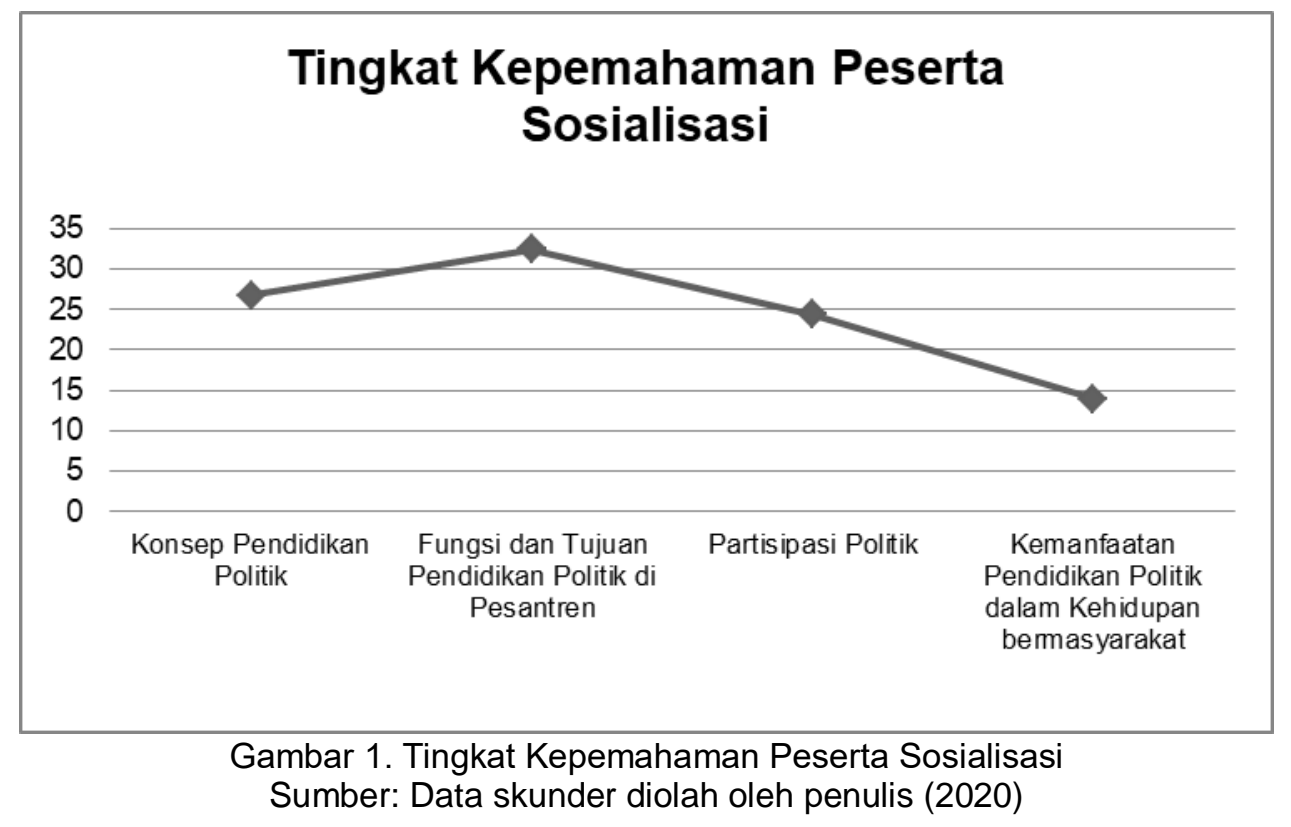

Dari gambar tersebut dapat diketahui bahwa rata-rata tingkat pemahaman peserta terhadap konsep pendidikan politik sebesar 26,73 , fungsi dan tujuan pendidikan politik di pesantren sebesar 32,44, partisipasi politik sebesar 24,35, dan kemanfaatan pendidikan politik dalam kehidupan bermasyarakat sebesar 13,91. Rata-rata tingkat pemahaman peserta terhadap kemanfaatan pendidikan politik dalam kehidupan bermasyarakat 
diketahui angkanya paling rendah, hal ini disebabkan karena adanya budaya di pesantren yang menganggap politik tidak ada hubungannya dengan santri.

Selain menggunakan form feedback, tingkat kepemahaman peserta terhadap materi dapat dilihat dari hasil diskusi dengan peserta.Para santri memberikan banyak tanggapan selama kegiatan penyuluhan berlangsung. Waktu penyampaian materi kurang lebih selama 3 jam, kemudian dilanjutkan dengan sesi tanya jawab terkait materi yang telah disampaikan. Pertanyaan dan tanggapan pun cukup banyak seperti:

1. Pengaruh politik bagi kehidupan mereka

2. Manfaat kalau santri paham politik, dimana masyarakat beranggapan bahwa santri adalah individu yang paham agama dan nantinya akan mengajarkan ajaran agama di masyarakat.

3. Kegunaan paham kebangsaan dalam meningkatkan kewaspadaan terhadap bahaya paham terorisme.

4. Peran santri dalam kehidupan berbangsa, bernegara dan berpolitik di Indonesia yang demokratis

Hambatan yang dialami oleh tim pengabdi dalam kegiatan ini bahwa sebanyak $70 \%$ yang terlibat adalah santri yang usianya 17 sampai 18 tahun, dimana pengetahuan umum mereka tentang pendidikan politik masih sangat rendah, sehingga perlu usaha yang cukup sabar untuk membuat mereka paham terhadap materi pendidikan politik yang disampaikan. Sedangkan mereka yang sudah berusia 20 tahun ke atas sudah memiliki bekal pemahaman tentang politik namun pemahaman mereka $90 \%$ memaknai politik itu sebagai hal yang negatif, merugikan dan berdampak buruk, jadi memerlukan pendekatan yang lebih hati-hati dalam menyampaikan makna pendidikan politik. Mengingat lokasi di pondok pesantren tradisonal yang menggunakan bahasa pengantar pembelajaran dengan bahasa Arab, Indonesia dan Jawa (bahasa daerah) banyak istilah asing yang sulit dipahami oleh tim pengabdi.

\section{KESIMPULAN}

Kegiatan pendidikan politik kebangsaan berbasis pesantren dapat dilaksanakan sesuai dengan tujuan kegiatan. Hal ini ditunjukkan dengan antusiame para santri dalam mengikuti kegiatan ini. Selain itu, dari hasil tanya jawab diketahui bahwa banyak santri dan pengurus pondok pesantren mengharapkan kegiatan serupa dapat dilaksankan setiap tahun, mengingat setiap tahun ada banyak santri yang memasuki usia sebagai pemilih dalam pemilu. Pengetahuan tentang pendidikan politik ini sangat diperlukan bagi para santri dan pengurus pondok pesantren, terutama untuk menghilangkan stigma negatif mereka terhadap makna politik di masyarakat yang selama ini dimaknai negatif.

Rekomendasi berdasarkan hasil evaluasi pasca kegiatan bahwa sebagai upaya untuk mengembangkan pengetahuan dan meningkatkan kewaspadaan para santri dalam pendidikan di luar agama (pendidikan umum 
dan kebangsaan), kegiatan seperti ini perlu dilaksanakan dengan rutin. Bentuk kegiatan yang paling efektif adalah berupa penyuluhan. Pesantren bisa lebih terbuka dalam melakukan pengembangan pengetahuan politik santrinya dengan melakukan kerjasama dengan lembaga lain yang berpengalaman.

\section{DAFTAR RUJUKAN}

Afif, M. (2019). Penerapan Metode Sorogan Dalam Meningkatkan Baca Kitab di Pondok Pesantren Tarbiyatun Nasyi'in. Kabilah: Journal of Social Community, 4(2), 34-43. https://doi.org/10.35127/kbl.v4i2.3592

Borge, J. A. Ø. (2016). Doctoral Dissentation-Creating Democratic Citizens 2016.pdf [Universitas

Bergensis]. http://bora.uib.no/bitstream/handle/1956/13138/dr-thesis-2016-JulieAne-Ødegaard-Borge.pdf?sequence $=1$

Ernas, S., \& Siregar, F. M. (2010). Dampak Ke terlibatan Pesantren dalam Politik: Studi Kasus Pesantren di Yogyakarta. Kontekstualita Jurnal Penelitian Sosial Keagamaan, 25(2), 195-224. http://ejournal..lp2m.uinjambi.ac.id/ojp/index.php/Kontekstualita/issue/view/34

Furqan, M. (2019). Surau dan Pesantren Sebagai Lembaga Pengembang Masyarakat Islam di Indonesia (Kajian Perspektif Historis). Jurnal Alljtimaiyyah: Media Kajian Pengembangan Masyarakat Islam, 5(1), 134. https://doi.org/10.22373/al-ijtimaiyyah.v5i1.5132

Hamid, A. (2010). Memetakan Aktor Politik Lokal Banten Pasca Orde Baru: Studi Kasus Kiai dan Jawara di Banten. Politika Jurnal IImu Politik, 1(2), 32-45. https://doi.org/10.14710/politika.1.2.2010.32-45

Heru Nugroho. (2012). Demokrasi Dan Demokratisasi: Sebuah Kerangka Konseptual Untuk Memahami Dinamika Sosial-Politik Di Indonesia. Jurnal Pemikiran Sosiologi, 1(1), 1-15. https://doi.org/10.22146/jps.v1i1.23419

JIS, D. C., Nindastu, P. I., \& Lubis, D. P. (2016). Alternatif Media Pendidikan Politik Dalam Rangka Membangun Partisipasi Politik Pemuda Tani. Jurnal Komunikasi Pembangunan, 14(1), 13-29. https://doi.org/10.46937/14201613549

Kalidjernih, F. K., \& Winarno. (2019). Dari terminologi ke subtansi pendidikan kewarganegaraan: Implikasi terhadap revitalisasi Pancasila. Jurnal Civics: Media Kajian Kewarganegaraan, 16(1), 51-58. https://doi.org/10.21831/jc.v16i1.25311

Maesaroh, N., \& Achdiani, Y. (2018). Tugas Dan Fungsi Pesantren Di Era Modern. Sosietas, 7(1), 346-352. https://doi.org/10.17509/sosietas.v7i1.10348

Mukodi. (2016). Pesantren dan Pendidikan Politik di Indonesia: Sebuah Reformulasi Kepemimpinan Islam Futuristik. Al-Tahrir: Jurnal Pemikiran Islam, 16(2), 461-484. https://doi.org/10.21154/altahrir.v16i2.503

Nadir, \& Wardani, W. Y. (2018). Membangun Pendidikan Politik Dalam Fatsun 
Demokrasi Pancasila Dan Deliberative. The Journal of Society and Media, 3(1), 126-141. https://doi.org/10.26740/jsm.v3n1.p126-141

Nugroho, W. (2016). Peran Pondok Pesantren dalam Pembinaan Keberagamaan Remaja. Mudarrisa, Jurnal Kajian Pendidikan Islam, 8(1), 89-116. https://doi.org/10.18326/mudarrisa.v8i1.89-116

Oladejo, A. O., \& Oni, E. O. (2017). Political Education and Community Development in Nigeria: Issues and Challenges. Canadian Social Science, 13(3), 45-54. https://doi.org/10.3968/9344

Olum, Y. (2014). Public accountability and good governance in Uganda's public sector. Journal of Public Administration, Jun(1), 603-621. https://doi.org/10520/EJC159970

Rusydiyah, E. F. (2017). Konstruksi Sosial Pendidikan Pesantren; Analisis Pemikiran Azyumardi Azra. Jurnal Pendidikan Agama Islam (Journal of Islamic Education Studies), 5(1), 21-43. https://doi.org/10.15642/jpai.2017.5.1.21-43

Sunarso. (2006). Membangun Masyarakat Demokrasi yang Bermoral Lewat Pendidikan Kewarganegaraan. Jurnal Civics: Media Kajian Kewarganegaraan, 3(1), 72-85. https://doi.org/10.21831/civics.v3i1.5736

Syafe'i, I. (2017). Pondok Pesantren: Lembaga Pendidikan Pembentukan Karakter. Al-Tadzkiyyah: Jurnal Pendidikan Islam, 8(1), 85-103. https://doi.org/10.24042/atjpi.v8i1.2097

Thahir, M. (2014). The Role and Function of Islamic Boarding School: An Indonesian Context. International Journal for Historical Studies, 5(2), 197-208. https://mindamas-journals.com/tawarikh/article/view/574

Thebe, T. P. (2017). Political education for good governance in South Africa ' s local. African Journal of Public Affairs, 9(5), 123-135.

Triono. (2017). Pemilu dan Urgenitas Pendidikan Politik Masyarakat dalam Mewujudkan Pemerintahan yang Baik. Jurnal Agregasi: Aksi Reformasi Government Dalam Demokrasi, 5(2), 214-232. https://doi.org/10.34010/agregasi.v5i2.447

Wahyuningroem, S. L. (2011). Perempuan diantara Reformasi Politik dan Reformasi Ekonomi: Peluang Peningkatan Keterwakilan Politik Perempuan Melalui Partisipasi Kerja. Jurnal Studi Politik Demokrasi Yang Adil Dan Setara, 1(2), 144-157. file://C:/Users/LPPM/AppData/Local/Temp/19-6-PB.pdf 